\title{
Evolution of a Bridge Builder Outreach Activity
}

\author{
Suzette R. Burckhard and Zach Gutzmer, Professor and Instructor, Civil and
} Environmental Engineering, South Dakota State University, Brookings, SD

\begin{abstract}
Many engineering outreach programs use building a bridge as a hands-on activity for multiple grade levels and audiences. South Dakota State University (SDSU) has used bridge building activities, with slight modifications for grade level and time allowed, for over 10 years in outreach at schools and campus workshops. In recent years, it has been noted that the same level of students attending these outreach events are either performing the same or a similar activity at their school or another event outside of our outreach program which has affected the effectiveness of using this activity to stimulate interest in engineering. In the last two years, modifications have been made to create a bridge builder challenge that incorporates measurement, experimentation, simulation, design, and redesign for middle and high school students. Therefore, -incorporation of design standards and performance as well as economic efficiency has been the key to linking science principles to engineering principles. Details of the activity and its implementation are discussed.
\end{abstract}

\section{Background}

A common goal for outreach activities is to increase the interest that participants have for math and science and, in turn, engineering. In an effort to entice more people to study engineering, outreach activities to schools and through workshops have increased in recent years ${ }^{1}$. One staple activity in many of these outreach activities is building a bridge. Many different bridge activities are available on-line for use in outreach or teaching ${ }^{2-5}$. Contests have been created to build and test balsa wood bridges and also virtual bridges, formerly known as West Point Bridge challenge ${ }^{6}$. The following article describes bridge building activities and anecdotal observations from 15 years of outreach workshops that have featured bridge building.

\section{Overview of Outreach Activities}

At South Dakota State University, bridge building has been used for numerous outreach activities. The American Society of Civil Engineers student chapter would build bridges with gumdrops or marshmallows and toothpicks at regional schools in the early 1990's. The Lohr College of Engineering hosts a balsa wood bridge contest as part of the annual Engineering Exposition. Recently, bridge building has been a featured activity in the Girls Engineering Math Science (GEMS) and Ready, Set, Go workshops offered to middle and high school girls. The bridges built in these workshops have varied from ones made with $\mathrm{K}^{\text {' }} \mathrm{Nex}^{\mathrm{TM}}$ to ones made with wooden craft sticks and hot glue. The week-long SDSU Youth Engineering Adventure (YEA), for high school students, has offered bridge building as an activity recently, replacing a tower building activity used for several years. 


\section{.Description of Bridge Activities}

The bridge building activities employed were very similar to each other with few variations. Each bridge building activity started with a short presentation on what is a bridge and types of bridges, with truss bridges highlighted; followed by a challenge to build a bridge. The materials to build a bridge are handed out and students work in small groups with supervision based on age level. The typical challenge is to build a bridge that will support the heaviest load. There may be restrictions added in terms of length or amount of materials. During the testing phase, bridges are tested until failure and the bridge that held the highest load is declared the winner. Table 1 describes the general design challenge and specifications for different bridge outreach activities.

Table 1: Descriptions of Bridge Design Challenge Criteria by type of SDSU Outreach Event

\begin{tabular}{|l|l|l|}
\hline Bridge outreach contest & Design challenge & Specifications \\
\hline Grade school outreach & $\begin{array}{l}\text { Build a bridge to hold the } \\
\text { most weight }\end{array}$ & $\begin{array}{l}\text { Provided materials, Length, } \\
\text { time restrictions }\end{array}$ \\
\hline Balsa Wood Bridge & $\begin{array}{l}\text { Build a bridge to hold the } \\
\text { most weight, aesthetics }\end{array}$ & $\begin{array}{l}\text { Material type and size, length, } \\
\text { height restrictions }\end{array}$ \\
\hline GEMS and Ready, Set, Go & $\begin{array}{l}\text { Build a bridge to hold the } \\
\text { most weight then changed to a } \\
\text { specified weight }\end{array}$ & $\begin{array}{l}\text { General length requirement, } \\
\text { most weight was replaced by } \\
\text { specified weight after first } \\
\text { offering, time, materials } \\
\text { provided restriction }\end{array}$ \\
\hline YEA & $\begin{array}{l}\text { Build a bridge to hold the } \\
\text { most weight }\end{array}$ & $\begin{array}{l}\text { time restrictions } \\
\text { menotided, }\end{array}$ \\
\hline
\end{tabular}

For the majority of the activities, the major goal of building a bridge was to hold the heaviest load which appealed to most of the students. A minority of students wanted to create aesthetically pleasing bridges and had less concern regarding the weight the bridge could hold. It was a challenge in some groups to have everyone involved in small groups and there were some participants who had never built anything and struggled with the open ended challenge.

\section{Analysis of Bridge Building Materials}

Different materials have been used in bridge building activities. The materials varied based on what was available, the cost, and the time allowed for the activity. Table 2 describes the different materials that have been used, their positive and negative attributes and what grade level the material was used for. 
Table 2. Positive and Negative Features of Different Bridge Building Materials Used for Different Grade Levels

\begin{tabular}{|c|c|c|c|}
\hline $\begin{array}{l}\text { Bridge building } \\
\text { material }\end{array}$ & Positives & Negatives & Grade Level \\
\hline $\begin{array}{l}\text { Gum drops and } \\
\text { marshmallows as } \\
\text { connectors with } \\
\text { Toothpicks or spaghetti } \\
\text { noodles as structural } \\
\text { members }\end{array}$ & $\begin{array}{l}\text { Easy to obtain, } \\
\text { inexpensive, does not } \\
\text { require much force to } \\
\text { assemble, able to make } \\
\text { bridge deck easily }\end{array}$ & $\begin{array}{l}\text { Makes a mess, } \\
\text { toothpicks are very } \\
\text { short but can substitute } \\
\text { skewers if available, } \\
\text { kids disappointed they } \\
\text { can't eat the pieces, } \\
\text { Too much force on } \\
\text { spaghetti causes it to } \\
\text { break }\end{array}$ & $\begin{array}{l}\text { Kindergarten to } \\
4^{\text {th }} \text { grade }\end{array}$ \\
\hline Balsa wood and glue & $\begin{array}{l}\text { Able to cut pieces to } \\
\text { custom lengths, readily } \\
\text { available materials }\end{array}$ & $\begin{array}{l}\text { Hard to control what } \\
\text { type of glue is used if } \\
\text { bridge is assembled off } \\
\text { premises then brought } \\
\text { for testing, requires } \\
\text { special items to be } \\
\text { purchased, bridge } \\
\text { decking connections } \\
\text { are not straightforward }\end{array}$ & $\begin{array}{l}\text { High School, } \\
\text { Middle School }\end{array}$ \\
\hline $\begin{array}{l}\text { Building sets } \\
\text { K’Nex }^{\mathrm{TM}} \text {, Pasco }{ }^{\mathrm{TM}} \text {, } \\
\text { Lego }^{\mathrm{TM}} \text {, Erector sets, } \\
\text { etc.) }\end{array}$ & $\begin{array}{l}\text { Can build sturdy } \\
\text { bridges quickly }\end{array}$ & $\begin{array}{l}\text { Some bridge sets do } \\
\text { not allow for testing } \\
\text { easily without a load } \\
\text { platform, can be } \\
\text { expensive to acquire } \\
\text { kits, kids don't get to } \\
\text { take them home }\end{array}$ & $\begin{array}{l}\text { High School, } \\
\text { Middle School }\end{array}$ \\
\hline $\begin{array}{l}\text { Wooden craft sticks and } \\
\text { hot glue }\end{array}$ & $\begin{array}{l}\text { Can build sturdy } \\
\text { bridges quickly }\end{array}$ & $\begin{array}{l}\text { Bridge designs are less } \\
\text { elaborate, activity can } \\
\text { quickly become arts } \\
\text { and crafts time, bridge } \\
\text { deck hard to attach }\end{array}$ & $\begin{array}{l}5^{\text {th }} \text { grade to High } \\
\text { School }\end{array}$ \\
\hline $\begin{array}{l}\text { File folders, paper, } \\
\text { cardboard }\end{array}$ & $\begin{array}{l}\text { Inexpensive, fairly } \\
\text { sturdy depending on } \\
\text { design }\end{array}$ & $\begin{array}{l}\text { Assembly takes time } \\
\text { and can be tedious, } \\
\text { little variation in bridge } \\
\text { designs, students lost } \\
\text { interest before bridge } \\
\text { was done }\end{array}$ & $\begin{array}{l}\text { Middle School, } \\
\text { High School }\end{array}$ \\
\hline
\end{tabular}

In general, the materials chosen have to fit the age limitations of the group. Younger children need easy to manipulate objects and may need a builder-mentor sitting with them to complete the activity. The builder-mentor can sit with a small group of four builders and help all of them as they build if the participants are working individually or assist the entire group if they are 
working as a group. The types of materials may dictate what type of bridge is built with deck bridges dominating activities that used wooden craft sticks even though the presentation stressed truss bridges. Even when additional materials are made available, such as paper clips, brads or index cards, the designs were very simplistic and few teams attempted truss bridges. Another limitation is the length of material supplied. Truss bridges can only be a certain configuration unless there is a quick, easy and safe manner to cut wooden craft sticks. Hot glue can be used for quick assembly but these would not work well for younger or more adventuresome students.

One unusual observation was made when working with a school that had a majority of students from low income families. A number of studentss in this outreach event had a concern about ruining food. Several students wanted to eat the creation they had made since they normally did not get to have gum drops. This revelation was surprising for some of the builder-mentors.

\section{Analysis of Single Session Bridge Builder Activities}

Bridge builder activities targeted to K-4 grade levels were perceived as fun and interesting. Participants enjoyed the contest of which bridge could hold the most weight. The participants did not necessarily associate bridge building with what an engineer might do. Activities targeted to middle school grade levels used more complex materials such as wooden sticks, hot glue, paper clips, brads, index cards and pins or building sets like $\mathrm{K}^{\prime} \mathrm{Nex}^{\mathrm{TM}}$. The participants built mostly deck bridges and if not given limitations on supplies, used extensive amounts of glue and sticks to make very sturdy bridges which carried heavy loads but were not economical or practical in many cases. Activities targeted to high school had similar results as those observed with the middle school participants. Aesthetically pleasing bridges made by some participants, although very artistic, were not practical as the deck was not complete in many cases. Again, the bridges built were not necessarily related to what an engineer might do.

\section{Uniqueness of Experiences}

In initial offerings of the hands-on activity to schools, students responded positively and found the activity to be fun. Most had not built a bridge or knew what engineers did. Younger students were able to work with the gumdrops and toothpicks to create small bridges and had a sense of accomplishment when they finished. Middle and high school students required a more complex bridge building system and materials. Most students liked the competitive nature of building a bridge that could hold the largest load. Students who were not as interested in the competition would build aesthetically pleasing structures that they did not want failed.

As we continued hosting outreach events, we had many of the same schools or teachers requesting the workshop. This resulted in some students experiencing the same or a similar workshop several times as limited records were kept of when we had visited certain schools as these were events sponsored by the student American Society of Civil Engineers organization. Teachers who had hosted the workshop previously were reluctant to host the same workshop again unless it had been several years.

In addition to the workshops, students were able to build bridges in new venues. In recent years, local organizations have included bridge building as part of a larger science day that students and 
parents could attend. Several museums and science centers, that have bridge building as part of hands-on exhibit, have come into existence. Anecdotally, students attending the middle school girls and high school girls outreach workshops, as well as the summer weeklong engineering experience, would make comments that they worked on West Point Bridge design in science or mathematics classes at school or bridge building in $4-\mathrm{H}$ and scouting events. Some students attending our workshops would lament 'not this again.' It was interesting to note that when we hosted high school science teachers for a workshop, they had never built bridges although they had bridges in their lesson plans or had worked with students participating in the Engineering Expo bridge design contest.

\section{YEA Bridge Builder Experience}

The YEA camp held each year at SDSU is a week-long engineering outreach camp where students get to participate in many different activities related to multiple areas of engineering. The bridge builder activity used for this camp started as a simple bridge design that had to span a 12 inch, flat gap. A presentation on bridges, stressing truss bridges, was made to the students before they were given materials to build with. Materials used started with $\mathrm{K}^{\text {' }} \mathrm{Nex}^{\mathrm{TM}}$. These bridges were truss type bridges but lacked a convenient testing method since the rods would pull out of the connectors as weights were added by hanging them from the completed bridge by the rods. The material used in a different challenge was changed to Pasco ${ }^{\mathrm{TM}}$ building systems which easily allowed for quick construction of truss bridges. These bridges supported very heavy loads which became a concern as the weights being applied were upwards of 100 pounds and might cause an injury to a participant when a bridge failed. The other concern was the cost of replacing failed structural members. Since these were specialized building sets, the cost was much greater than household materials or $\mathrm{K}^{\prime} \mathrm{Nex}^{\mathrm{TM}}$ pieces. The challenge was changed to not fail the bridge but have the least deflection or movement of the bridge. The Pasco ${ }^{\mathrm{TM}}$ building system was very robust so light weights did not cause the bridges to deflect which made judging the winner of the event more challenging.

The next iteration of the activity was to provide wooden sticks, hot glue, pins, paper clips, brads, index cards, rubber bands, string, and pins. The participant groups could choose any combination of the building materials to build a bridge to span a 12 inch, flat gap within the time limit of 2 to 3 hours. When not limited by materials, the groups over-built and made mostly deck bridges. There were few truss bridges due to the size of the wooden sticks and the inability to attach a deck to a truss bridge easily. Some groups attempted suspension or cable stayed bridges but the gap provided did not include any proper connections for cable stays on the gap edges. Again, the activity, although more challenging, did not become associated with what engineers might do.

Before we made additional changes to the activity, we discussed our observations and concerns. The major concern was that the bridges being built were not being engineered. The emphasis for a number of years had been to make sure the activity was fun, which was achieved, but there was little connection to the engineering design process. Figure 1 shows an idealized view of the engineering design process. 


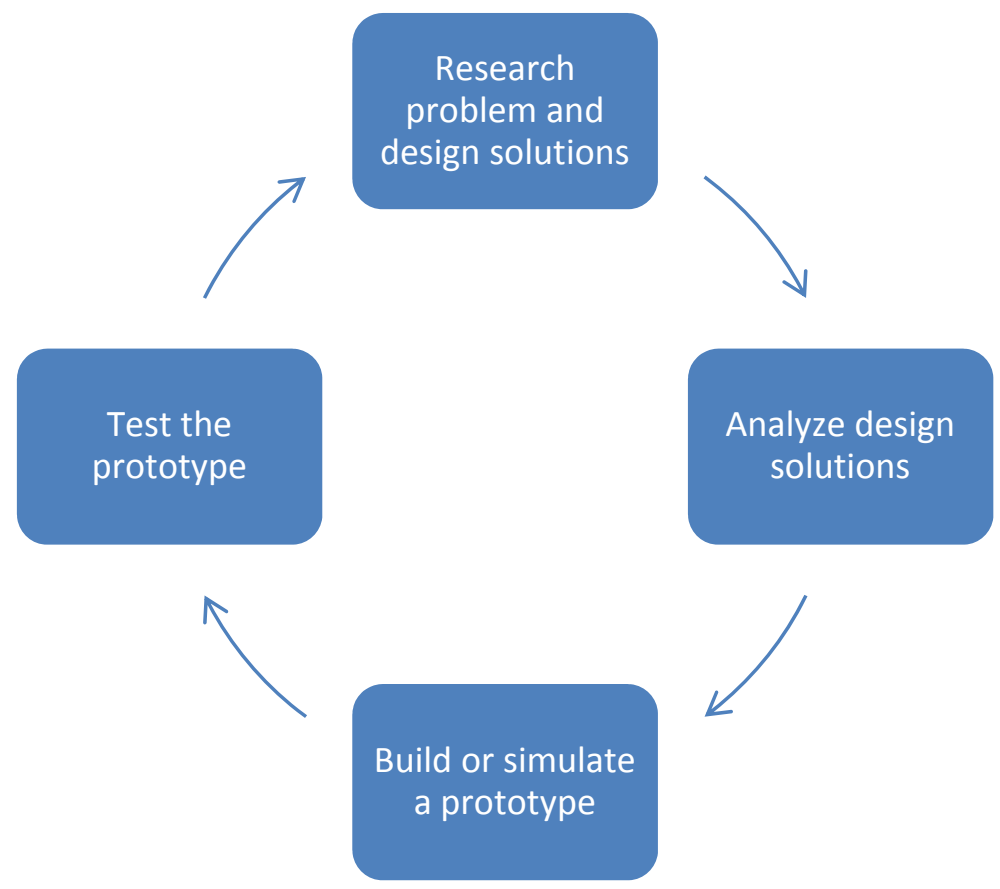

Figure 1: A representation of the engineering design process.

We concentrated on the engineering design process to design a better activity that incorporates the engineering design steps in an overt manner. The new activity consists of four distinct activities that follow a presentation on structural engineering. Details of the activity are shown below.

- Presentation on structural engineering emphasizing structural elements and how the elements could be used to create different bridge types

- Examine the effect that bridge length, height, number of bays, and material has on deflection under an applied load. Fifteen bridges were constructed of Pasco ${ }^{\mathrm{TM}}$ members. These bridges were tested over a specified flat gap with a specific load. Participants were to measure deflection at mid span and, after testing all the bridges, graph the results to determine the effect that the variables (height, width, weight, number of members, etc.) had on deflection.

- Test bridge building material properties and experiment with bridge designs. Participants were asked to test materials (wooden sticks, hot glue, pins, paper clips, brads, index cards, rubber bands, string, and pins) in three point, tension, or compression configuration in singles and combined.

- Simulate building a bridge under different constraints: length, elevation difference across a gap, number of bays, connection points, materials, and loads. Cargo Bridge ${ }^{7}$ was chosen as the bridge simulator since it allowed for quick design, build and test sequence with engineering constraints as well as being fun

- Build a bridge according to a specified length and offset elevation to carry a specified load according to a given scenario. Materials have to be purchased and the overall purchase price cannot exceed a given budget. The scenario was that a bridge had washed out leaving a town stranded and a bridge needed to be constructed to deliver supplies to 
the other side. The supplies were three cans of food which were taller than the length of a wooden stick.

The new bridge building challenge has been undertaken by three separate groups; two high school student groups and one high school teacher group. In the first offering of the revised bridge builder activity, the majority of the bridges met the design specification and the groups did not exceed their budget. In the second offering, we changed the specified gap to be longer with an off center location for a bridge pier to be built so the bridge would be an arc shape. In this challenge, only two of twelve bridges passed the load without failing. The most common failure was the load falling off narrow bridges. In the third offering, two of four teacherdesigned and built bridges passed the load although the teachers were more creative in what they built. They had requested power tools to machine the ends of the wooden sticks to create more complex bridges.

The participants in the bridge building challenge did enjoy the activity and took more time to design a bridge before building although there was still an element of design as you build during the activity. The groups did not spend their entire budget. Deck bridges were a common design type followed by truss and suspension bridges. Most bridges were fairly narrow compared to the load that needed to be carried. Most of the effort and design was focused on the bridge deck with little time spent on the support column design, especially how the column was to connect to the bridge deck. Many of the failures were related to the location or type of bridge column.

\section{Lessons Learned}

The lessons we learned were as follows.

- The activity had to include the engineering design process.

- If there are no constraints on materials, there will be little engineering design. Setting a budget and choosing different pricing points for construction materials can be used to push participants to consider other designs, i.e. suspension versus solid wooden stick deck.

- The gap to be spanned needed to be more complex.

- A bridge which requires column support as well as being placed on the gap edges requires more thought as there is the design of the bridge and the support columns.

- By splitting the activity into smaller, distinct phases, different parts of the engineering design process can be emphasized.

- Adding activities such as taking and graphing data emphasizes science principles as well as leading participants through the engineering design process and showing how science and engineering are related.

- Including simulation in a fun manner allowed for more engineering design and testing.

- Changing between activities allowed individuals with different learning styles and personalities to participate in manners they preferred.

- High tech solutions (bridge building kits) did not show appreciable differences in participant attitude but did decrease the fun factor.

- Working with students from poverty stricken backgrounds required sensitivity to their experiences. 
- Girls and traditionally under-represented individuals also required a different approach such as making sure girls were not outnumbered in groups, making sure each student in a group was able to design and simulate and to make sure the opinions and work that everyone did was valued in some manner. These recommendations are based on studies noting learning differences and attitudes between boys and girls ${ }^{8-9}$.

- Make sure the mentors who assist with the activity actually understand the purpose as well as having an understanding of how to manipulate the materials to create a bridge, i.e. let them work through the activity before presenting it to the students.

- Clarify to the mentors that they may need to instruct the students in how to handle tools or work with their hands.

\section{Bibliography}

1. Andrew T. Jeffers, Angela G. Safferman, and Steven I. Safferman (2004). ”Understanding K-12 Engineering Outreach Programs.” J. Prof. Issues Eng. Educ. Pract., 130(2), 95-108.

2. Teach Engineering (2014), Hands on activity: Straw Bridges, available on-line at http://www.teachengineering.org/view_activity.php?url=collection/cub_activities/cub_brid/cub_brid_lesson01 activity2.xml, accessed on July 21, 2014.

3. NOVA (2014) Build a Bridge, available on-line at: http://www.pbs.org/wgbh/nova/tech/build-bridge-p1.html, accessed on July 21, 2014.

4. Try Engineering (2014) Popsicle Bridge, available on-line at: http://www.tryengineering.org/lessons/popsiclebridge.pdf, accessed on July 21, 2014.

5. Don Demember (2014) Bridges, available on-line at: http://www.discoveryeducation.com/teachers/free-lessonplans/bridges.cfm, accessed on July 21, 2014.

6. Engineering Encounter (2014), Bridge Design Contest, available on-line at http://bridgecontest.org/ accessed on June, 12, 2014.

7. Limex Games (2014) Cargo Bridge available on-line at http://limexgames.com/studio/games/cargo_bridge, accessed on June 12, 2014.

8. Catsambis, S. (1995). Gender, race, ethnicity, and science education in the middle grades. Journal of Research in Science Teaching, 32(3), 243-257.

9. Connell, R. (1996). Teaching the boys: New research on masculinity, and gender strategies for schools. The Teachers College Record, 98(2), 206-235. 